\title{
Clear sky UV simulations for the 21st century based on ozone and temperature projections from Chemistry-Climate Models
}

\author{
K. Tourpali ${ }^{1}$, A. F. Bais ${ }^{1}$, A. Kazantzidis ${ }^{1}$, C. S. Zerefos ${ }^{2}$, H. Akiyoshi ${ }^{3}$, J. Austin ${ }^{4}$, C. Brühl ${ }^{5}$, N. Butchart ${ }^{6}$, \\ M. P. Chipperfield ${ }^{7}$, M. Dameris ${ }^{8}$, M. Deushi ${ }^{9}$, V. Eyring ${ }^{8}$, M. A. Giorgetta ${ }^{10}$, D. E. Kinnison ${ }^{11}$, E. Mancini ${ }^{12}$, \\ D. R. Marsh ${ }^{11}$, T. Nagashima ${ }^{3}$, G. Pitari ${ }^{12}$, D. A. Plummer ${ }^{13}$, E. Rozanov ${ }^{14}$, K. Shibata ${ }^{9}$, and W. Tian ${ }^{7}$ \\ ${ }^{1}$ Laboratory of Atmospheric Physics, Aristotle University of Thessaloniki, Greece \\ ${ }^{2}$ Laboratory of Climatology, Faculty of Geology, University of Athens, Greece \\ ${ }^{3}$ National Institute for Environmental Studies, Tsukuba, Japan \\ ${ }^{4}$ UCAR/NOAA Geophysical Fluid Dynamics Laboratory, Princeton, New Jersey, USA \\ ${ }^{5}$ Max-Planck-Institut für Chemie, Mainz, Germany \\ ${ }^{6}$ Met Office Climate Research Division, Exeter, UK \\ ${ }^{7}$ Institute for Atmospheric Science, University of Leeds, UK \\ ${ }^{8}$ Deutsches Zentrum für Luft- und Raumfahrt, Institut für Physik der Atmosphäre, Oberpfaffenhofen, Germany \\ ${ }^{9}$ Meteorological Research Institute, Tsukuba, Japan \\ ${ }^{10}$ Max-Plank-Institut für Meteorologie, Hamburg, Germany \\ ${ }^{11}$ National Center for Atmospheric Research, Boulder, CO, USA \\ ${ }^{12}$ Università L'Aquila, Dipartimento di Fisica, L'Aquila, Italy \\ ${ }^{13}$ Environment Canada, Toronto, Ontario, Canada \\ ${ }^{14}$ Institute for Atmospheric and Climate Science ETHZ and Physical-Meteorological Observatory, Davos, \\ World Radiation Centre, Switzerland
}

Received: 15 April 2008 - Published in Atmos. Chem. Phys. Discuss.: 9 July 2008

Revised: 8 December 2008 - Accepted: 15 January 2009 - Published: 16 February 2009

\begin{abstract}
We have estimated changes in surface solar ultraviolet (UV) radiation under cloud free conditions in the 21 st century based on simulations of 11 coupled ChemistryClimate Models (CCMs). The total ozone columns and vertical profiles of ozone and temperature projected from CCMs were used as input to a radiative transfer model in order to calculate the corresponding erythemal irradiance levels. Time series of monthly erythemal irradiance received at the surface during local noon are presented for the period 1960 to 2100. Starting from the first decade of the 21st century, the surface erythemal irradiance decreases globally as a result of the projected stratospheric ozone recovery at rates that are larger in the first half of the 21st century and smaller towards its end. This decreasing tendency varies with latitude, being more pronounced over areas where stratospheric ozone
\end{abstract}

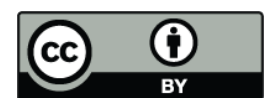

Correspondence to: $\mathrm{K}$. Tourpali (tourpali@auth.gr) has been depleted the most after 1980. Between 2000 and 2100 surface erythemal irradiance is projected to decrease over midlatitudes by 5 to $15 \%$, while at the southern high latitudes the decrease is twice as much. In this study we have not included effects from changes in cloudiness, surface reflectivity and tropospheric aerosol loading, which will likely be affected in the future due to climate change. Consequently, over some areas the actual changes in future UV radiation may be different depending on the evolution of these parameters.

\section{Introduction}

In the past three decades, stratospheric ozone depletion has been a high priority environmental concern, due to the consequent increase in solar ultraviolet radiation reaching the earth's surface (e.g., Herman et al., 1999; Kerr et al., 2003), and related skin cancer risks (e.g., Slaper et al., 1996). The

Published by Copernicus Publications on behalf of the European Geosciences Union. 
variability of surface UV radiation in the past has been extensively investigated using both measured and reconstructed records (e.g., Lindfors et al., 2007; Lindfors and Vuilleumier, 2005; Feister et al., 2008; den Outer et al., 2005; Krzyscin et al., 2004; Rieder et al., 2008; Chubarova, 2008), showing increasing of UV irradiance in response to the observed ozone reductions in the 1980s and 1990s. Recent observations suggest that the concentration of ozone depleting substances in the atmosphere have started to decrease as a result of the measures taken under the Montreal Protocol and its Amendments and Adjustments (WMO, 2007). Future levels of surface UV radiation will depend on the evolution of various factors, known to influence the propagation of solar UV radiation in the atmosphere. Some of these factors, such as ozone, clouds, and surface reflectivity are included in standard output products of coupled Chemistry-Climate Models (CCMs) (e.g., Eyring et al., 2006, 2007). The prediction of future aerosol levels and their optical characteristics are also very important for the attenuation of UV radiation, but this is more complex and a topic of ongoing research. Under cloud free skies, the most important factors affecting UV radiation are stratospheric ozone, followed by tropospheric ozone and aerosols and, to a lesser extent, $\mathrm{SO}_{2}, \mathrm{NO}_{2}$ and other trace gases in the atmosphere of urban areas. The effects of ozone depend on its column abundance, but also on its vertical distribution and the corresponding temperature at each level (Lapeta et al., 2000; Kazantzidis, 2005; McKenzie et al., 2003; Bruhl and Crutzen, 1989). Prediction of future surface UV levels can be achieved through radiative transfer model calculations using the above-mentioned factors as input (Bais et al., 2007). Erythemally weighted irradiance (McKinlay and Diffey, 1987) is here chosen as a suitable parameter to quantify future UV levels. The quantity depends on irradiance over a broad spectral region in the ultraviolet and provides a direct link to the harmful biological effects of UV radiation.

In order to simulate surface erythemal irradiance fields for the 21 st century, we use here monthly mean total ozone and zonal-mean vertical profiles of ozone and temperature as projected by the CCMs which participated in the CCM Validation Activity (CCMVal) for the WCRP's (World Climate Research Programme) of SPARC (Stratospheric Processes and their Role in Climate project). All irradiance simulations have been carried out assuming cloud free skies, since, at present, information about the future levels of the other UV influencing factors is either uncertain (e.g., clouds) or not available in a form that could be used in radiative transfer calculations (e.g., cloud and aerosol optical thickness in the ultraviolet at different altitudes).

\section{Methodology and data}

Eleven CCMs (see Table 1) which took part in the CCMVal reference simulations for the future ("REF2") were used to provide zonal-mean ozone and temperature profiles and total ozone column, for the entire globe for UV irradiance calculations (Eyring et al., 2005a, b, 2007). The CCMVal standard output of these reference simulations did not include information on clouds. Greenhouse gases (GHGs) in the simulations followed the IPCC (Intergovernmental Panel on Climate Change) SRES (Special Report on Emission Scenarios) (IPCC, 2002) A1B (medium) scenario and surface halogens were prescribed according to the Ab scenario of WMO (2003). Sea surface temperatures (SSTs) and sea ice concentrations in the CCM simulations were taken from coupled atmosphere-ocean model projections using the same GHG scenario. REF2 includes only anthropogenic forcings, while natural forcings, such as solar variability, were not generally included, and no external forcing was employed to enforce the quasi biennial oscillation (QBO) in CCMs lacking the capability of simulating the QBO as an internal mode of variability. However, AMTRAC and E39C models include future solar forcing and E39C includes also an externally forced QBO. Basic information on the CCMs considered in this study is given in Table 1, and further details are given in the listed reference for each model. For two models, there are differences from the description of the runs as given in Eyring et al. (2007): (a) the run from CCSRNIES model has been extended until 2100, and (b) the MRI model group provided new runs, extended until 2080, with improved transport of chemical species (Shibata and Deushi, 2008).

Each model provided simulated monthly mean results on different grids. The results were linearly interpolated to a standard $5^{\circ} \times 5^{\circ}$ grid, which was used in the radiative transfer model calculations of surface UV irradiance. All models resolve the atmosphere at up to the lower mesosphere or higher, except E39C which resolves the atmosphere only up to $10 \mathrm{hPa}$. For this model, the temperature and ozone profiles for the region above the $10 \mathrm{hPa}$ level were taken from the AFGL model atmosphere (Anderson et al., 1986) for the appropriate latitude and season. The upward extended ozone profiles of E39C were scaled to match the total ozone column simulated by this model in each grid point and month.

For the UV irradiance calculations we used the UVSPEC model of the libRadtran package (Mayer and Kylling, 2005) with the DISORT solver running with 6 streams (Stamnes and Swanson, 1981; Stamnes et al., 1988). Surface UV reflectivity was set to 0.05 , except for the polar regions where it was set to 0.7. For the aerosol optical depth, the default profile by Elterman (1968) was used. This profile results in a columnar optical depth of 0.38 at $340 \mathrm{~nm}$, which is certainly not appropriate for all locations and for the future atmosphere, but is more realistic than assuming an atmosphere free of aerosols. It should be noted that there is no quantitative information on the evolution of tropospheric aerosol loading in the 21st century, an issue that was not addressed in the CCMVal simulations used here. Consequently, in the CCM runs it was assumed that the stratospheric aerosol profile will remain constant at 1999 levels, when the volcanic 
Table 1. A summary of the Climate Chemistry Models used in this study.

\begin{tabular}{|c|c|c|c|c|}
\hline Name of model & Domain/resolution & $\begin{array}{l}\text { No/type of } \\
\text { model runs }\end{array}$ & $\begin{array}{l}\text { Period of } \\
\text { simulation }\end{array}$ & References \\
\hline AMTRAC & $2^{\circ} \times 2.5^{\circ}, \mathrm{L} 48,0.0017 \mathrm{hPa}$ & $3 \times \mathrm{REF} 2$ & 1990-2099 & Austin and Wilson (2006); Austin et al. (2007) \\
\hline CCSRNIES & $\mathrm{T} 42, \mathrm{~L} 34,0.01 \mathrm{hPa}$ & $1 \times \mathrm{REF} 2$ & $1980-2100$ & $\begin{array}{l}\text { Akiyoshi et al. (2004); Shiogama et al. (2005); } \\
\text { Kurokawa et al. (2005) }\end{array}$ \\
\hline CMAM & $\mathrm{T} 32, \mathrm{~L} 71,0.0006 \mathrm{hPa}$ & $3 \times \mathrm{REF} 2$ & 1960-2099 & de Grandpré et al. (2000); Beagley et al. (1997) \\
\hline E39C & $\mathrm{T} 30, \mathrm{~L} 39,10 \mathrm{hPa}$ & $3 \times \mathrm{SCN} 2$ & $2000-2019$ & Dameris et al. $(2005,2006)$ \\
\hline GEOSCCM & $2^{\circ} \times 2.5^{\circ}, \mathrm{L} 55,0.01 \mathrm{hPa}$ & $1 \times$ REF2 & $2000-2099$ & Stolarski et al. (2006); Pawson et al. (2008) \\
\hline MAECHAM4/CHEM & $\mathrm{T} 30, \mathrm{~L} 39,0.01 \mathrm{hPa}$ & $1 \times \mathrm{REF} 2$ & $2000-2019$ & Manzini et al. (2003); Steil et al. (2003) \\
\hline MRI & $\mathrm{T} 42, \mathrm{~L} 68,0.01 \mathrm{hPa}$ & $1 \times \mathrm{REF} 2$ & $1980-2080$ & Shibata et al. (2005); Shibata and Deushi (2005) \\
\hline SOCOL & $\mathrm{T} 30, \mathrm{~L} 39,0.01 \mathrm{hPa}$ & $1 \times \mathrm{REF} 2$ & $1980-2050$ & Rozanov et al. (2005); Egorova et al. (2005) \\
\hline ULAQ & $10^{\circ} \times 22.5^{\circ}, \mathrm{L} 26,0.04 \mathrm{hPa}$ & $1 \times \mathrm{REF} 2$ & $1980-2050$ & Pitari et al. (2002) \\
\hline UMSLIMCAT & $2.5^{\circ} \times 3.75^{\circ}, \mathrm{L} 64,0.01 \mathrm{hPa}$ & $1 \times \mathrm{REF} 2$ & $1980-2019$ & Tian and Chipperfield (2005) \\
\hline WACCM (v.3) & $4^{\circ} \times 5^{\circ}, \mathrm{L} 66,4.5 \times 10-6 \mathrm{hPa}$ & $3 \times \mathrm{REF} 2$ & $1980-2050$ & Garcia et al. (2007) \\
\hline
\end{tabular}

influence had declined, to the end of the simulations. In this study we are primarily concerned with relative changes in erythemal irradiance throughout the 21 st century which are practically unaffected when constant aerosols are used for the entire period in the UV simulations. However, future (unpredicted) volcanic eruptions could in practice have important impacts on atmospheric ozone amounts, and surface UV. Contrary to aerosols, the attenuation of UV radiation by clouds has a weak spectral dependence, resulting in a constant reduction factor which cancels out when calculating relative changes of irradiance between different years.

Based on the data described above (monthly means of gridded total ozone and zonal averages of ozone and temperature profiles), the erythemal irradiance for the solar zenith angle corresponding to the local noon of the 15 th of each month was calculated for the entire grid $\left(5^{\circ} \times 5^{\circ}\right)$. These gridded values were then zonally averaged. All results are presented here as relative changes (in \%) from the corresponding monthly means of the 10-year average of the period 1996 through 2005. For the models which were initialised from the year 2000 (E39C, GEOSCCM, and, MAECHAM4/CHEM), we calculated the 6-year average from 2000 through 2005. Finally, when there were more than one simulations available for a particular model (i.e. AMTRAC, E39C, CMAM and WACCM) the ensemble average was calculated from the individual runs of that model.

In this study we focus on future surface UV irradiance as a relative rather than absolute change, since the absolute total ozone is slightly different for each CCM (for details see Eyring et al., 2007). This therefore demonstrates the relative effect on UV radiation of changes in ozone, as changes in the other major factors, such as clouds, aerosol and surface reflectivity, are not included in the calculations.
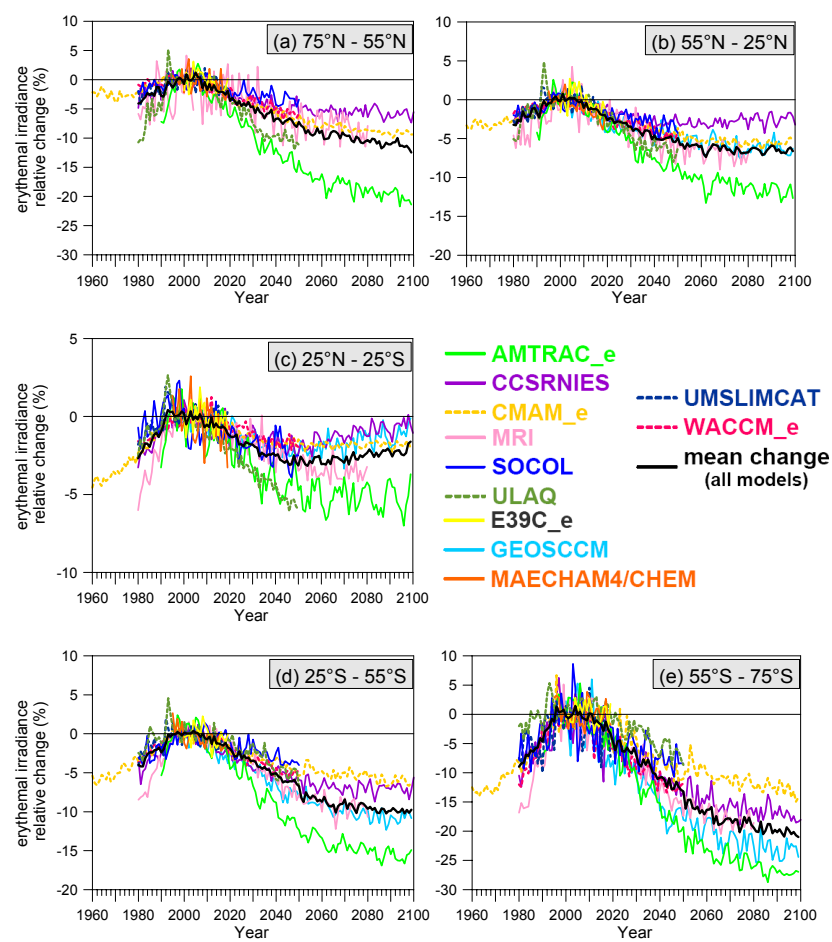

Fig. 1. Time series of annually averaged surface erythemal irradiance changes relative to the mean over the period 1996-2005, as zonal means for five latitude belts denoted on each panel. Lines of different colours correspond to calculations based on results from different CCMs (indicated with the same colour in the right-middle panel. The suffix “_e” in the model names indicates ensemble means (average of multiple runs). The black line represents the average change from all models.

\section{Results}

Figure 1 shows annually and zonally averaged changes in surface erythemal irradiance relative to the average of the 

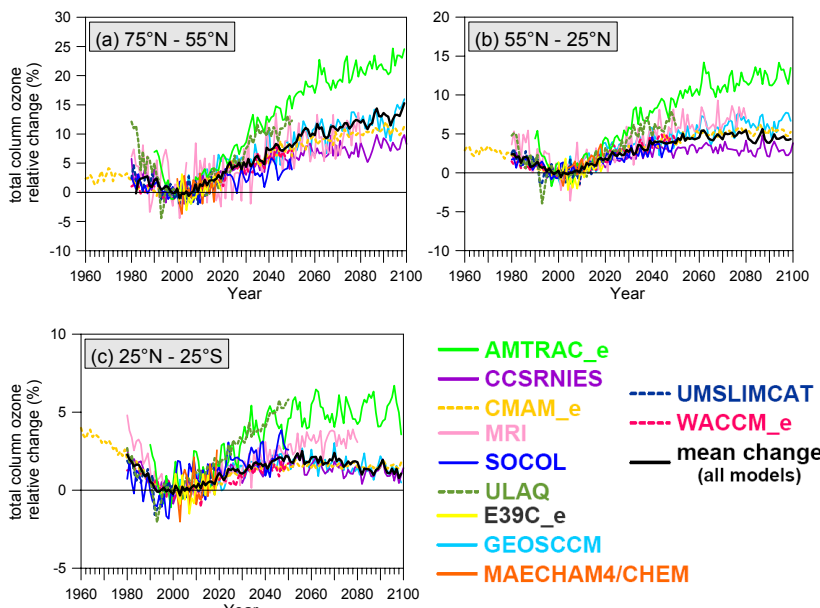

- SOCOL
--- ULAQ
E39C_e - GEOSCCM - MAECHAM $4 / \mathrm{CHEM}$
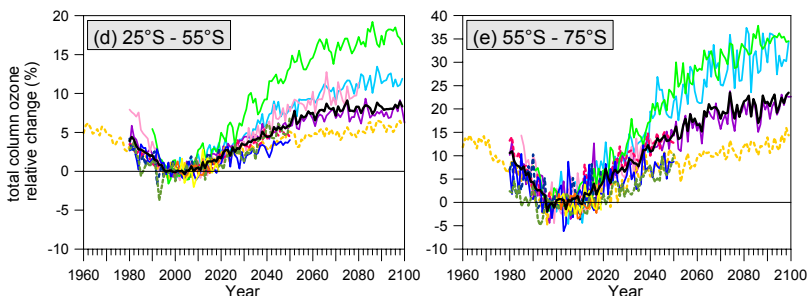

Fig. 2. Same as Fig. 1 but for total column ozone simulated by the CCMs used in this study.

period $1996-2005$ for the latitude belts $75^{\circ} \mathrm{N}-55^{\circ} \mathrm{N}, 55^{\circ} \mathrm{N}-$ $25^{\circ} \mathrm{N}, 25^{\circ} \mathrm{N}-25^{\circ} \mathrm{S}, 25^{\circ} \mathrm{S}-55^{\circ} \mathrm{S}$, and $55^{\circ} \mathrm{S}-75^{\circ} \mathrm{S}$, representing the high and the middle latitudes of the two hemispheres and the tropics. The changes are shown as annual means in order to eliminate the short term variability caused by the seasonal variations of the simulated ozone.

The erythemal irradiance under cloud-free skies starts to decrease after the first two decades of the 21st century, with higher rates in the high latitudes of both hemispheres, reflecting the projected ozone recovery for the next few decades, shown in Fig. 2 and discussed in detail in Eyring et al. (2007). The changes in ozone have been calculated in the same way as the changes in UV irradiance. In the tropics, the erythemal irradiance changes are smaller in absolute value but still negative. The highest UV levels have been calculated for the period 1990-2010, when the simulated ozone has reached its minimum. The negative relative changes of irradiance during the 1980s and early 1990s suggest that total ozone, as simulated by the CCMs, had not reached its minimum until early 2000s. These changes in irradiance for the northern middle and high latitudes are generally smaller than $\sim 5 \%$ per decade, and they are in accordance with the changes reported for various locations over Europe from measured or reconstructed irradiance data (e.g., Krzyscin et al., 2004; Lindfors et al., 2007; den Outer et al., 2005; Feister et al., 2008; Rieder et al., 2008; Chubarova, 2008).
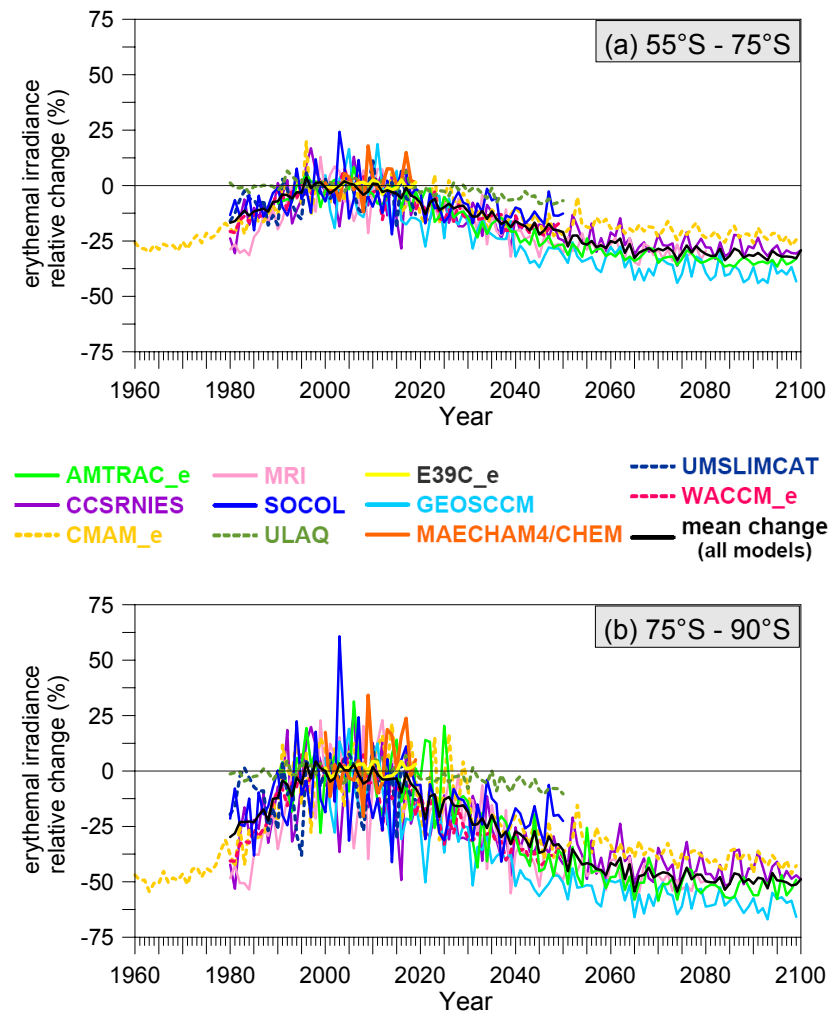

Fig. 3. Same as Fig. 1 but for erythemal irradiance changes averaged for October and November and for the two most southern latitude belts, $55^{\circ} \mathrm{S}-75^{\circ} \mathrm{S}$ (top) and $75^{\circ} \mathrm{S}-90^{\circ} \mathrm{S}$ (bottom).

The magnitude of the calculated changes in erythemal irradiance varies significantly, as a result of the variations in the predicted ozone columns from the CCMs. After the first quarter of the $21 \mathrm{st}$ century the calculated relative changes start to diverge among the models, especially after 2050 when results from only four models (two with multiple runs) are available. The projected reduction of erythemal irradiance towards 2100 ranges between $5 \%$ and $15 \%$ for midlatitudes and is only a few percent in the tropics. At the southern high latitudes the reductions are about twice as large, ranging from about $10 \%$ to $25 \%$.

The evolution of the erythemal irradiance changes in the two southernmost latitude belts averaged over the months of October and November is shown in Fig. 3. During this season the Antarctic ozone hole reaches its maximum in area and intensity. The simulated ozone columns from all CCMs show a marked interannual variability at these latitudes, hence the erythemal irradiance presents a similarly high interannual variability. In the $55^{\circ}-75^{\circ} \mathrm{S}$ belt, the predicted erythemal irradiance changes are negative for all models after about 2020 , reaching on the average $-25 \%$ in 2100 . At the southernmost belt $\left(75^{\circ}-90^{\circ} \mathrm{S}\right)$ the relative changes are negative for all models about 10 years later than in midlatitudes, and are larger in magnitude ( - 40\% in 2100). During this season, 

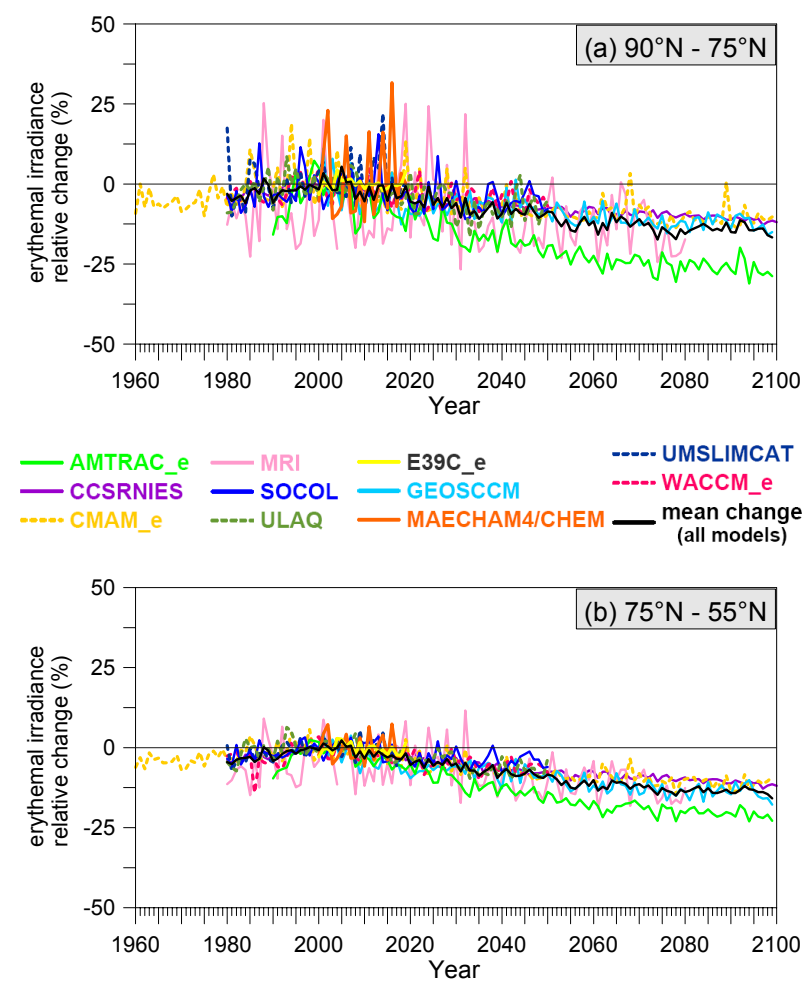

Fig. 4. Same as Fig. 1 but for erythemal irradiance changes averaged for March and April and for the two most northern latitude belts, $75^{\circ} \mathrm{N}-90^{\circ} \mathrm{N}$ (top) and $55^{\circ} \mathrm{N}-75^{\circ} \mathrm{N}$ (bottom).

the variability for the other latitude belts (not shown here) is much smaller, i.e. similar to the annual patterns presented in Fig. 1. All these changes in erythemal irradiance reflect the corresponding changes in the simulated ozone fields.

In Fig. 4 the relative changes in surface erythemal irradiance for the northern high and polar latitudes and for late winter - early spring months (March-April) are presented (note the different ordinates between Figs. 2 and 3). Again the inter-annual variability of the ozone field simulated by each CCM is large, especially in the polar regions and especially for the MRI model. Nevertheless the variability is smaller than in the Southern Hemisphere. The pronounced decrease in UV irradiance is attributed to the predicted ozone recovery from about the mid 2020s, earlier than in the Southern Hemisphere. These changes are about half those in the Southern Hemisphere (Fig. 3).

In the case of ensemble simulations, as made by the AMTRAC, E39C, CMAM and WACCM models, the variability between the ensemble members is large in the polar regions, mainly in the late winter - early spring months, such as October in the Southern and March in the Northern Hemisphere. This variability, suppressed in the annual or seasonal averages, remains large until about the mid 2030s and is reduced afterwards. However, the spread between ensemble members of any model used in ensemble mode is smaller than the spread among all the models. This holds for CMAM, for

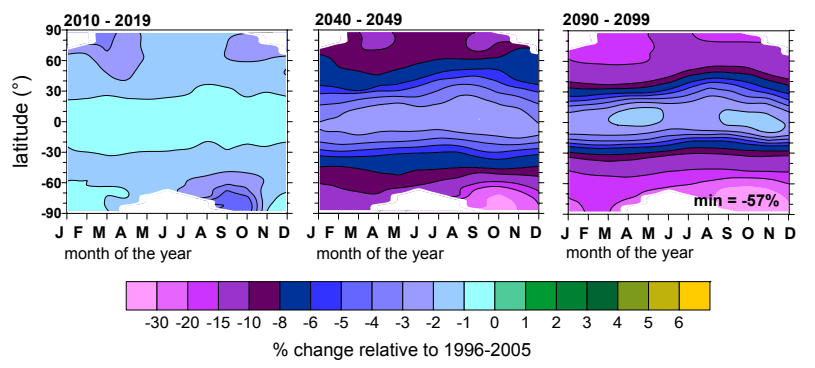

Fig. 5. Changes (in \%) of erythemal irradiance averages for the period 2010-2019 (left panel), 2040-2049 (middle panel) and 20902099 (right panel) relative to the 1996-2005 average as a function of season and latitude. The erythemal irradiance was calculated for the local noon of the 15 th of each month and under cloud free skies and reflect the predicted changes in total ozone by the CCMs. The model results included in each panel are dependent on the simulation period covered by each model (Table 1).

which the three different ensemble members result from the forcing by different SSTs, as well as for AMTRAC, E39C and WACCM, where the three different ensemble members result from different initial states.

Figure 5 shows the change in the clear-sky erythemal irradiance averaged over three decades (2010-2019, 2040-2049 and 2090-2099) of the 21st century relative to the 1996-2005 average as a function of season and latitude, averaged over all the models. In the 2010 s, the changes relative to the period 1996-2005 are predicted to be small (of the order of 1-2\%), and only in the Southern Hemisphere spring there are signs of greater reductions. In the 2040s and particularly in the 2090s, erythemal irradiance is calculated to be lower than in the 1996-2005 decade over all latitudes for the entire calendar year. The smallest changes, of the order of a few percent, are predicted for the tropical region while more pronounced changes occur in higher latitudes. The Antarctic region exhibits the largest reduction, up to $47 \%$, in the spring period. All these reductions are a result of the projected recovery of the ozone layer.

\section{Discussion and conclusions}

In all the calculations presented here we have used total ozone data together with the vertical ozone and temperature distribution provided by the CCMs. However, even if we had used only the total ozone and constant ozone profiles from AFGL scaled to match the temporally varying ozone columns, the results would have been very similar to those discussed above, at least outside the polar regions. In the polar regions, the difference is of the order of a few percent, reflected mostly in the year-to-year variability of each model. The negative correlation between total ozone and surface UV irradiance is so high, that total ozone might be viewed as the most important component in predicting future UV irradiance levels under clear skies and constant aerosol loading. 
Future UV levels are likely to be affected by other factors influenced by climate change, such as cloudiness, aerosols and surface albedo. Therefore the changes in erythemal irradiance after the middle of the 21st century presented here may change substantially, even reverse in sign (e.g. for reduced cloudiness), depending on season and latitude. According to the Fourth Assessment Report (AR4) of the IPCC (Meehl et al., 2007 and in particular their Fig. 10), multimodel simulations based on the SRESA1B scenario suggest that cloud cover will decrease by the end of the 21st century in most of the low and middle latitudes of both hemispheres by up to $4 \%$. This would result in an increase in surface UV radiation in these regions (e.g. by about $4 \%$ for erythemal irradiance), counteracting the decrease from ozone recovery. The opposite is expected in high latitudes and in a few lowlatitude regions where cloud cover is predicted to increase.

A decrease in surface reflectivity in the high to polar latitudes of both hemispheres due to reduction of ice covered areas (e.g., Comiso et al., 2008; Overland and Wang, 2007) would result in a decrease of surface UV radiation over these and neighbouring areas, enhancing the projected decrease in surface erythemal irradiance due to changes in ozone. Surface reflectivity enhances the upwelling radiation, part of which is backscattered by air molecules towards the surface, thus increasing the irradiance at the surface and over areas within several kilometres.

In conclusion, the projected recovery of the ozone layer during the 21st century in conjunction with the expected changes in other UV influencing factors due to climate changes are expected to modify accordingly the erythemal solar irradiance at the Earth's surface. In general decreases are largest in areas where the ozone depletion has been most pronounced, such as over Antarctica. The calculated UV changes have large uncertainties due to the approximations inherent in the assumptions for cloudiness, aerosols and surface albedo. It is anticipated that the uncertainties will become smaller as these climate change parameters are taken in to account in proposed future simulations for CCMVal and related scientific activities.

Acknowledgements. This work has been conducted in the framework of the EC Integrated Project SCOUT-O3 (contract 505390-GOCE-CT-2004). Co-ordination of this study was supported by the Chemistry-Climate Model Validation Activity (CCMVal) for WCRP's (World Climate Research Programme) SPARC (Stratospheric Processes and their Role in Climate) project. We thank the British Atmospheric Data Center for assistance with the CCMVal Archive. The future run of CCM SOCOL was supported by the Swiss National Science Foundation (grant SCOPES IB7320-110884). CCRNIES' and MRI's research was supported by the Global Environmental Research Fund (GERF) of the Ministry of the Environment (MOE) of Japan (A-071). The National Center for Atmospheric Research is sponsored by the US National Science Foundation.

Edited by: U. Pöschl

\section{References}

Akiyoshi, H., Sugita, T., Kanzawa, H., and Kawamoto, N.: Ozone perturbations in the Arctic summer lower stratosphere as a reflection of NOX chemistry and planetary scale wave activity, J. Geophys. Res., 109, D03304, doi:03310.01029/02003JD003632, 2004.

Anderson, G. P., Clough, S. A., Kneizys, F. X., Chetwynd, J. H., and Shettle, E. P.: AFGL atmospheric constituent profiles (0120 km), Tech. Rep. AFGL-TR-86-0110, Mass., Air Force Geophys. Lab., Hascom Air Force Base, 1986.

Austin, J. and Wilson, R. J.: Ensemble simulations of the decline and recovery of stratospheric ozone, J. Geophys. Res., 111, D16314, doi:16310.11029/12005JD006907, 2006.

Austin, J., Wilson, R. J., Li, F., and Vömel, H.: Evolution of water vapor concentrations and stratospheric age of air in coupled chemistry-climate model simulations, J. Atmos. Sci., 64(3), 905921, 2007.

Bais, A. F., Lubin, D., Arola, A., Bernhard, G., Blumthaler, M., Chubarova, N., Erlick, C., Gies, H. P., Krotkov, N., Lantz, K., Mayer, B., McKenzie, R. L., Piacentini, R., Seckmeyer, G., Slusser, J. R., and Zerefos, C.: Surface ultraviolet radiation: Past, present and future, Geneva, Switzerland, Chapter 7 in Scientific Assessment of Ozone Depletion: 2006, Global Ozone Research and Monitoring Project, Report No. 47, World Meteorological Organization, 58, 2007.

Beagley, S. R., Grandpré, J. D., Koshyk, J. N., McFarlane, N. A., and Shepherd, T. G.: Radiative- dynamical climatology of the first-generation Canadian Middle Atmosphere Model, Atmos. Ocean, 35, 293-331, 1997.

Brühl, C. and Crutzen, P. J.: On the disproportionate role of tropospheric ozone as a filter against solar UV-B radiation, Geophys. Res. Lett., 16(7), 703-706, 1989.

Chubarova, N. Y.: UV variability in Moscow according to longterm UV measurements and reconstruction model, Atmos. Chem. Phys., 8, 3025-3031, 2008, http://www.atmos-chem-phys.net/8/3025/2008/.

Comiso, J. C., Parkinson, C. L., Gersten, R., and Stock, L.: Accelerated decline in the Arctic sea ice cover, Geophys. Res. Lett., 35, L01703, doi:01710.01029/02007GL031972, 2008.

Dameris, M., Grewe, V., Ponater, M., Deckert, R., Eyring, V., Mager, F., Matthes, S., Schnadt, C., Stenke, A., Steil, B., Brühl, C., and Giorgetta, M. A.: Long-term changes and variability in a transient simulation with a chemistry-climate model employing realistic forcing, Atmos. Chem. Phys., 5, 2121-2145, 2005, http://www.atmos-chem-phys.net/5/2121/2005/.

Dameris, M., Matthes, S., Deckert, R., Grewe, V., and Ponater, M.: Solar cycle effect delays onset of ozone recovery, Geophys. Res. Lett., 33, L03806, doi:03810.01029/02005GL024741, 2006.

de Grandpré, J., Beagley, S. R., Fomichev, V. I., Griffioen, E., McConnell, J. C., Medvedev, A. S., and Shepherd, T. G.: Ozone climatology using interactive chemistry: Results from the Canadian Middle Atmosphere Model, J. Geophys. Res., 105, 2647526491, 2000.

den Outer, P. N., Slaper, H., and Tax, R. B.: UV radiation in the Netherlands: Assessing long-term variability and trends in relation to ozone and clouds, J. Geophys. Res., 110, D02203, doi:02210.01029/02004JD004824, 2005.

Egorova, T., Rozanov, E., Zubov, V., Manzini, E., Schmutz, W., and Peter, T.: Chemistry-climate model SOCOL: a validation of 
the present-day climatology, Atmos. Chem. Phys., 5, 1557-1576, 2005, http://www.atmos-chem-phys.net/5/1557/2005/.

Elterman, L.: UV, visible, and IR attenuation for altitudes to $50 \mathrm{~km}$, Bedford, MA, USA, Air Force Cambridge Research Laboratories, 1968.

Eyring, V., Harris, N. R. P., Rex, M., Shepherd, T. G., Fahey, D. W., Amanatidis, G. T., Austin, J., Chipperfield, M. P., Dameris, M., Forster, P. M. D. F., Gettelman, A., Graf, H. F., Nagashima, T., Newman, P. A., Pawson, S., Prather, M. J., Pyle, J. A., Salawitch, R. J., Santer, B. D., and Waugh, D. W.: A strategy for processoriented validation of coupled chemistry-climate models, B. Am. Meteorol. Soc., 86, 1117-1133, 2005a.

Eyring, V., Butchart, N., Waugh, D. W., Akiyoshi, H., Austin, J., Bekki, S., Bodeker, G. E., Boville, B. A., Brühl, C., Chipperfield, M. P., Cordero, E., Dameris, M., Deushi, M., Fioletov, V. E., Frith, S. M., Garcia, R. R., Gettelman, A., Giorgetta, M. A., Grewe, V., Jourdain, L., Kinnison, D. E., Mancini, E., Manzini, E., Marchand, M., Marsh, D. R., Nagashima, T., Newman, P. A., Nielsen, J. E., Pawson, S., Pitari, G., Plummer, D. A., Rozanov, E., Schraner, M., Shepherd, T. G., Shibata, K., Stolarski, R. S., Struthers, H., Tian, W., and Yoshiki, M.: Assessment of temperature, trace species, and ozone in chemistry-climate model simulations of the recent past, J. Geophys. Res., 111, D22308, doi:22310.21029/22006JD007327, 2006

Eyring, V., Waugh, D. W., Bodeker, G. E., Cordero, E., Akiyoshi, H., Austin, J., Beagley, S. R., Boville, B. A., Braesicke, P., Brühl, C., Butchart, N., Chipperfield, M. P., Dameris, M., Deckert, R., Deushi, M., Frith, S. M., Garcia, R. R., Gettelman, A., Giorgetta, M. A., Kinnison, D. E., Mancini, E., Manzini, E., Marsh, D. R., Matthes, S., Nagashima, T., Newman, P. A., Nielsen, J. E., Pawson, S., Pitari, G., Plummer, D. A., Rozanov, E., Schraner, M., Scinocca, J. F., Semeniuk, K., Shepherd, T. G., Shibata, K., Steil, B., Stolarski, R. S., Tian, W., and Yoshiki, M.: Multi-model projections of stratospheric ozone in the 21st century, J. Geophys. Res., 112, D16303, doi:16310.11029/12006JD008332, 2007.

Feister, U., Junk, J., Woldt, M., Bais, A., Helbig, A., Janouch, M., Josefsson, W., Kazantzidis, A., Lindfors, A., den Outer, P. N., and Slaper, H.: Long-term solar UV radiation reconstructed by ANN modelling with emphasis on spatial characteristics of input data, Atmos. Chem. Phys., 8, 3107-3118, 2008, http://www.atmos-chem-phys.net/8/3107/2008/.

Garcia, R. R., Marsh, D. R., Kinnison, D. E., Boville, B. A., and Sassi, F.: Simulation of secular trends in the middle atmosphere, 1950-2003, J. Geophys. Res., 112, D09301, doi:09310.01029/02006JD007485, 2007.

Herman, J. R., McKenzie, R. L., Diaz, S. B., Kerr, J. B., Madronich, S., and Seckmeyer, G.: Ultraviolet radiation at the Earth's surface, in: UNEP/WMO Scientific Assessment of the Ozone Layer: 1998, edited by: Albritton, D. L., Aucamp, P. J., Megie, G., and Watson, R. T., 9, Global Ozone Research and Monitoring Project, Report No. 44, World Meteorological Organization, Geneva, Switzerland, 9.1-9.46, 1999.

IPCC: Special Report on Emissions Scenarios, Intergovernmental Panel on Climate Change, Cambridge University Press, Cambridge, UK, 612, 2002.

Kazantzidis, A., Bais, A. F., Balis, D. S., Kosmidis, E., and Zerefos, C. S.: Sensitivity of solar UV radiation to ozone and temperature profiles at Thessaloniki $\left(40.5^{\circ} \mathrm{N}, 23^{\circ} \mathrm{E}\right)$, Greece, J. Atmos. Sol.Terr. Phy., 67(14), 1321-1330, 2005.
Kerr, J. B., Seckmeyer, G., Bais, A. F., Bernhard, G., Blumthaler M., Diaz, S. B., Krotkov, N. A., Lubin, D., McKenzie, R. L., Sabziparvar, A. A., and Verdebout, J.: Surface ultraviolet radiation: Past and future, Geneva, Chapter 5 in Scientific Assessment of Ozone Depletion: 2002, Global Ozone Research and Monitoring Project, Report No. 47, World Meteorological Organization, 2003.

Krzyscin, J. W., Eerme, K., and Janouch, M.: Long-term variations of the UV-B radiation over Central Europe as derived from the reconstructed UV time series, Ann. Geophys., 22, 1473-1485, 2004, http://www.ann-geophys.net/22/1473/2004/.

Kurokawa, J., Akiyoshi, H., Nagashima, T., Masunaga, H., Nakajima, T., Takahashi, M., and Nakane, H.: Effects of atmospheric sphericity on stratospheric chemistry and dynamics over Antarctica, J. Geophys. Res., 110, D21305, doi:21310.21029/22005JD005798, 2005.

Lapeta, B., Engelson, O., Litynska, Z., Kois, B., and Kylling, A.: Sensitivity of surface UV radiation and ozone column retrieval to ozone and temperature profiles, J. Geophys. Res., 105, 50015007, 2000.

Lindfors, A. and Vuilleumier, L.: Erythemal UV at Davos (Switzerland), 1926-2003, estimated using total ozone, sunshine duration, and snow depth, J. Geophys. Res., 110, D02104, doi:02110.01029/02004JD005231, 2005.

Lindfors, A., Kaurola, J., Arola, A., Koskela, T., Lakkala, K., Josefsson, W., Olseth, J. A., and Johnsen, B.: A method for reconstruction of past UV radiation based on radiative transfer modeling: Applied to four stations in northern Europe, J. Geophys. Res., 112, D23201, doi:23210.21029/22007JD008454, 2007.

Manzini, E., Steil, B., Brühl, C., Giorgetta, M. A., and Krüger, K.: A new interactive chemistry climate model. 2: Sensitivity of the middle atmosphere to ozone depletion and increase in greenhouse gases: implications for recent stratospheric cooling, J. Geophys. Res., 108(D18), 4429, doi:10.1029/2002JD002977, 2003.

Mayer, B. and Kylling, A.: Technical note: The libRadtran software package for radiative transfer calculations - description and examples of use, Atmos. Chem. Phys., 5, 1855-1877, 2005, http://www.atmos-chem-phys.net/5/1855/2005/.

McKenzie, R., Smale, D., Bodeker, G., and Claude, H.: Ozone profile differences between Europe and New Zealand: Effects on surface UV irradiance and its estimation from satellite sensors, J. Geophys. Res., 108, 4179, doi:4110.1029/2002JD002770, 2003.

McKinlay, A. F. and Diffey, B. L.: A Reference Action Spectrum for Ultra-violet Induced Erythema in Human Skin, in: Human Exposure to Ultraviolet Radiation: Risks and Regulations, edited by: Passchier, W. F. and Bosnajakovic, B. F. M., Elsevier, Amsterdam, The Netherlands, 83-87, 1987.

Meehl, G. A., Stocker, T. F., Collins, W. D., Friedlingstein, P., Gaye, A. T., Gregory, J. M., Kitoh, A., Knutti, R., Murphy, J. M., Noda, A., Raper, S. C. B., Watterson, I. G., Weaver, A. J., and Zhao, Z.-C.: Global Climate Projections, in: Climate Change 2007: The Physical Science Basis, Contribution of Working Group I to the Fourth Assessment Report of the Intergovernmental Panel on Climate Change, edited by: Solomon, S., Qin, D., Manning, M., Chen, Z., Marquis, M., Averyt, K. B., Tignor, M., and Miller, H. L., Cambridge University Press, Cambridge, UK and New York, NY, USA, 99, 2007.

Overland, J. E. and Wang, M.: Future regional Arc- 
tic sea ice declines, Geophys. Res. Lett., 34, L17705, doi:17710.11029/12007GL030808, 2007.

Pawson, S., Stolarski, R. S., Douglass, A. R., Newman, P. A., Nielsen, J. E., Frith, S. H., and Gupta, M. L.: Goddard Earth Observing System Chemistry-Climate Model Simulations of Stratospheric Ozone-Temperature Coupling Between 1950 and 2005, J. Geophys. Res., 113, D12103, doi:12110.11029/12007JD009511, 2008.

Pitari, G., Mancini, E., Rizi, V., and Shindell, D.: Feedback of future climate and sulfur emission changes on stratospheric aerosols and ozone, J. Atmos. Sci., 59, 414-440, 2002.

Rieder, H. E., Holawe, F., Simic, S., Blumthaler, M., Krzyścin, J. W., Wagner, J. E., Schmalwieser, A. W., and Weihs, P.: Reconstruction of erythemal UV-doses for two stations in Austria: a comparison between alpine and urban regions, Atmos. Chem. Phys., 8, 6309-6323, 2008,

http://www.atmos-chem-phys.net/8/6309/2008/.

Rozanov, E., Schraner, M., Schnadt, C., Egorova, T., Wild, M., Ohmura, A., Zubov, V., Schmutz, W., and Peter, T.: Assessment of the ozone and temperature variability during 1979-1993 with the chemistry-climate model SOCOL, Adv. Space Res., 35, 1375-1384, 2005.

Shibata, K. and Deushi, M.: Partitioning between resolved wave forcing and unresolved gravity wave forcing to the quasi-biennial oscillation as revealed with a coupled chemistry-climate model, Geophys. Res. Lett., 32, L12820, doi:12810.11029/12005GL022885, 2005.

Shibata, K., Deushi, M., Sekiyama, T. T., and Yoshimura, H.: Development of an MRI chemical transport model for the study of stratospheric chemistry, Pap. Meteorol. Geophys., 55, 75-119, 2005.

Shibata, K. and Deushi, M.: Long-term variations and trends in the simulation of the middle atmosphere 1980-2004 by the chemistry-climate model of the Meteorological Research Institute, Ann. Geophys., 26, 1299-1326, 2008, http://www.ann-geophys.net/26/1299/2008/.
Shiogama, H., Watanabe, M., Kimoto, M., and Nozawa, T.: Anthropogenic and natural forcing impacts on ENSO-like decadal variability during the second half of the 20th century, Geophys. Res. Lett., 32, L21714, doi:21710.21029/22005GL023871, 2005.

Slaper, H., Velders, G. J. M., Daniel, J. S., de Gruijl, F. R., and van der Leun, J. C.: Estimates of ozone depletion and skin cancer incidence to examine the Vienna convention achievements, Nature, 384, 256-258, 1996.

Stamnes, K. and Swanson, R. A.: A new look at the discrete ordinate method for radiative transfer calculations in anisotropically scattering atmospheres, J. Atmos. Sci., 38, 387-399, 1981.

Stamnes, K., Tsay, S.-C., Wiscombe, W., and Jayaweera, K.: Numerically stable algorithm for discrete-ordinate-method radiative transfer in multiple scattering and emitting layered media, Appl. Opt., 27, 2502-2509, 1988.

Steil, B., Bruhl, C., Manzini, E., Crutzen, P. J., Lelieveld, J., Rasch, P. J., Roeckner, E., and Kruger, K.: A new interactive chemistry-climate model: 1 . Present-day climatology and interannual variability of the middle atmosphere using the model and 9 years of HALOE/UARS data, J. Geophys. Res., 108, 4290, doi:4210.1029/2002JD002971, 2003.

Stolarski, R. S., Douglass, A. R., Steenrod, S., and Pawson, S.: Trends in stratospheric ozone: Lessons learned from a 3D chemical transport model, J. Atmos. Sci., 63, 1028-1041, doi:1010.1175/JAS3650.1021, 2006.

Tian, W. and Chipperfield, M. P.: A new coupled chemistry-climate model for the stratosphere: The importance of coupling for future O3-climate predictions, Q. J. Roy. Meteorol. Soc., 131, 281-304, 2005.

WMO: Scientific Assessment of Ozone Depletion: 2002, World Meteorological Organisation, Geneva, Global Ozone Research and Monitoring Project, Report No. 47, 498, 2003.

WMO: Scientific Assessment of Ozone Depletion: 2006, World Meteorological Organisation, Geneva, Switzerland, Global ozone Research and Monitoring Project, Report No. 50, 572, 2007. 